\title{
PERANCANGAN SISTEM ABSENSI PEGAWAI BERBASIS WEB Studi Kasus : Kantor Kecamatan Purwodadi
}

\author{
1)Subiantoro, ${ }^{2)}$ Sardiarinto \\ 1) Manajemen Informatika, AMIK BSI Yogyakarta \\ subiantoro558@gmail.com \\ 2) Teknik Informatika, AMIK BSI Purwokerto \\ sardiarinto.sdo@bsi.ac.id
}

\begin{abstract}
Abstrak
Absensi kehadiran pegawai merupakan faktor penting bagi sebuah instansi atau perusahaan untuk mencapai tujuan, hal ini berkaitan pada kedisiplinan dan berdampak pada kinerja dari masing-masing pegawai. Oleh karena itu, perlu adanya pendataan khusus untuk mencatat absensi kehadiran dan ketidakhadiran agar aktifitas kerja dapat tercatat secara realtime dan baik. Banyak cara yang dapat dilakukan untuk mencapai sistem informasi absensi yang baik, salah satunya menggunakan teknologi komputer dimana penerapannya dengan aplikasi absensi berbasis website. Pada Kantor Kecamatan Purwodadi sistem yang digunakan dalam proses absensi masih manual menggunakan buku absensi harian yang berdampak pada efisiensi dan efektifitas pendataan, pencarian data sekaligus perhitungan rekap data yang membutuhkan waktu yang relatif lama. Disamping itu resiko kesalahan dan kehilangan data absensi semakin besar. Berdasarkan permasalahan diatas dibuatlah Sistem Informasi Absensi Kepegawaian Pada Kantor Kecamatan Purwodadi. Metode penelitian merupakan metode yang digunakan dalam pengumpulan data yang meliputi: metode riset, wawancara dan pustaka. Sedangkan pengembangan perangkat lunak menggunakan waterfall yang meliputi : analisa kebutuhan, desain, pengkodean, pengujian dan implementasi. Dengan dihasilkannya aplikasi absensi kepegawaian berbasis web dapat memberikan kemudahan dalam proses absensi, pencarian data dan perhitungan rekap absensi, serta meminimalisir kehilangan dan kesalahan pencatatan data absensi pada Kantor Kecamatan Purwodadi.
\end{abstract}

Kata Kunci: Sistem Informasi, Absensi Karyawan, Berbasis Web

\section{Abstract}

Attendance data is an important factor for the institution or to achieve its objectives, this is related to discipline and affects every employee. Therefore, there is a need to issue data specifically to report and find activities that can be done in real time and good. There are many ways that can be done to achieve a good information system, one of which uses computer technology where the application is with an application-based attendance website. The Purwodadi District Office system which is still in manual attendance using books, data and data recapitulation calculations takes a relatively long time. In addition, data and data shows are larger. Based on the context, an employee attendance information system is created in the Purwodadi Regional Office. The research method is the method used in the data which includes: research methods, interviews and literature. While the development of software using waterfall which includes: needs analysis, design, coding, testing and implementation. With the attendance results employees can provide assistance in the attendance process, search data and recapitulation, and explore and record attendance data at Purwodadi District Office.

Keywords: Information Systems, Employee Attendance, Web-Based

\section{Pendahuluan}

Absensi merupakan suatu hal yang penting dalam sebuah instansi pemerintah. Dengan sistem absensi yang baik maka diharapkan dapat membantu dalam mengendalikan proses penyelesaian pekerjaan sehingga didapatkan hasil yang maksimal dan sesuai dengan tujuan yang ditetapkan. Untuk mencapai sistem informasi absensi yang baik maka diperlukan teknologi informasi yang meliputi teknologi komputer, teknologi telekomunikasi dan teknologi apapun yang dapat memberikan nilai tambah untuk mengelola sistem tersebut(Jogiyanto, 2009). Absensi atau kartu jam hadir adalah dokumen yang mencatat jam hadir setiap pegawai di suatu perusahaan yang dapat 
berupa daftar hadir biasa atau kartu hadir yang diisi dengan mesin pencatat waktu(Setiawan, 2015). Kantor Kecamatan Purwodadi Kabupaten Purworejo merupakan salah satu instansi Pemerintah yang mempunyai tanggung jawab terhadap pelayanan masyakarakat dalam bidang pelayanan sosial. Jumlah pegawai yang dimiliki saat ini 48 personel dan dapat bertambah sesuai kebutuhan instansi. Semakin besar instansi pemerintah maka akan berdampak semakin besar pula dengan Sumber Daya Manusia (SDM) yang dibutuhkan. Berdasarkan hal itu maka instansi pemerintah dituntut untuk melakukan manajemen pengolahan data absensi yang baik, cepat dan dan efisien. Karena pada dasarnya sistem informasi absensi digunakan sebagai salah satu tolak ukur metode pengembangan pegawai, jika dalam absensi pegawai setelah mengikuti pengembangan menurun, maka metode pengembangan yang diterapkan berjalan dengan baik, sebaliknya jika absensi pegawai tetap berarti metode pengambangan yang diterapkan kurang baik (Hasibuan, 2008).

Prosedur absensi di Kantor Kecamatan Purwodadi yang diterapkan sekarang ini dapat dikatakan masih kurang efisien dan efektif, dimana semua masih dilakukan secara manual mulai dari pendataan dan perhitungan jam hadir, jam keluar, sampai dengan keterangan tidak masuk, hal ini berdampak pada waktu yang relatif lama dalam proses perhitungan rekapitulasi absensi dari pegawai, serta bentuk laporan absensi yang dibuat berupa hardcopy yang dapat menyebabkan kesalahan dalam pencatatan data, menyulitkan dalam proses pencarian data dan dapat dikhawatirkan terjadi kehilangan data absensi pegawai.

Untuk mengatasi hal tersebut diperlukan adanya sistem absensi berbasis web dengan intranet. Website adalah halaman informasi yang disediakan melalui jalur internet sehingga bisa diakses di seluruh dunia, selama terkoneksi dengan jaringan internet(Puspitosari, 2010). Sedangkan Intranet merupakan jaringan komputer didalam suatu organisasi yang menggunakan teknologi internet, menyediakan lingkungan yang mirip dengan internet, sehingga memungkinkan saling berbagai informasi(Mulyanto dalam O'Brien, 2009). Dengan adanya aplikasi tersebut diharapkan mampu meminimalisir permasalahan-permasalahan absensi yang ada di Kantor Kecamatan Purwodadi.

\section{Metode Penelitian}

Metode penelitian yang penulis gunakan untuk pengembangan perangkat lunaknya yaitu menggunakan model air terjun (waterfall). Model ini merupakan pendekatan perangkat lunak secara terurut yang dimulai dari analisis, desain, pengkodean, pengujian dan tahap pendukung(Rosa dan Shalahudin, 2013). Bentuk kerangka penelitian ini dapat dilihat pada gambar 1 berikut.

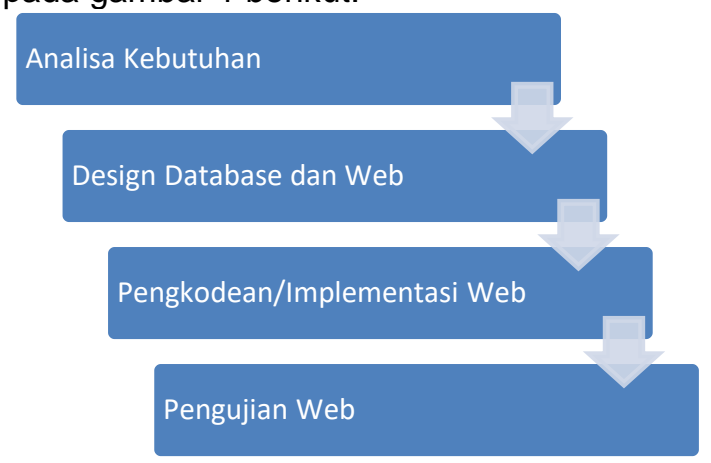

Gambar 1. Bentuk Kerangka Penelitian

\section{Hasil dan Pembahasan \\ 3.1. Analisa Kebutuhan}

Dalam perancangan website Sistem Informasi Absensi Kantor Kecamatan Purwodadi, memiliki kebutuhan fungsional dari masing-masing pengguna adalah sebagai berikut:

1. Kebutuhan Pengguna

Kebutuhan pengguna yang digunakan dalam pembanguna website Sistem Informasi Absensi Kepegawaian adalah sebagai berikut:

a. Kebutuhan Admin

1) Admin melakukan login sebelum masuk kehalaman administrator dengan menggunakan id_user dan password.

2) Admin dapat menambah, mengubah password, dan menghapus data administrator .

3) Admin dapat menambah data pegawai pada halaman login .

4) Admin dapat melakukan proses absensi kepegawaian.

5) Admin dapat mengubah dan menghapus data pegawai.

6) Admin dapat menambah, mengubah dan menghapus data pegawai, bagian, jabatan ,pelatihan, kenaikan jabatan. 
7) Admin dapat melihat dan mencetak laporan data pegawai, data pelatihan, data absensi.

b. Kebutuhan Pegawai

1) Pegawai dapat menambahkan data pegawai pada halaman login pegawai.

2) Pegawai melakukan login sebelum masuk kehalaman index pegawai dengan menggunakan NIP sebagai id_petugas dan password yang telah terdaftar.

3) Pegawai dapat melakukan proses absensi masuk dan proses absensi keluar berdasarkan waktu pada halaman absensi

4) Pegawai dapat mengubah data pegawai, password.

5) Pegawai dapat menambah, mengubah, dan menghapus data riwayat pendidikan data pengalaman kerja.

2. Kebutuhan Sistem

Kebutuhan sistem dalam perancangan website Sistem Informasi Absensi Kepegawaian Kantor Kecamatan Purwodadi adalah sebagai berikut:

a. Analisa Kebutuhan Sistem untuk Admin

1) Sistem melakukan validasi username dan password.

2) Sistem akan memberikan hak akses kepada Admin untuk dapat masuk ke halaman administrator jika username dan password sesuai.

3) Sistem akan menolak hak akses kepada Admin jika username dan password tidak sesuai.

4) Sistem menyediakan fasilitas untuk dapat menambah, mengubah, dan menghapus beberapa data yang digunakan untuk menampilkan secara keseluruhan pada website
Absensi Kepegawaian Kantor Kecamatan Purwodadi.

5) Sistem akan menghentikan akses Admin pada halaman administrator apabila telah melakukan proses logout.

c. Analisa Kebutuhan Sistem untuk Pegawai

1) Sistem melakukan validasi username dan password untuk masuk ke halaman user

2) Sistem akan memberikan hak akses kepada user untuk dapat masuk ke halaman user jika username dan password sesuai.

3) Sistem akan menolak hak akses kepada user jika username dan password tidak sesuai.

4) Sistem menyediakan fasilitas untuk dapat menambah, mengubah, dan menghapus beberapa data yang digunakan untuk menampilkan data absensi.

5) Sistem melakukan penyimpanan data absensi yang dilakukan oleh user.

6) Sistem akan menghentikan akses user pada halaman user apabila telah melakukan proses logout.

\subsection{Design Sistem}

ERD(Entity Relationship Diagram)

Entity Relationship Diagram (ERD)

adalah suatu diagram untuk menggambarkan desain konseptual dari model konseptual suatu basis data relasional. Entity Relationship Diagram (ERD) juga merupakan gambaran yang menghubungkan antara objek satu dengan objek yang lain dalam dunia nyata(Utami dan Hartanto, 2012). Bentuk rancangan ERD dalam pengembangan sistem ini dapat dilihat pada gambar 2 . 


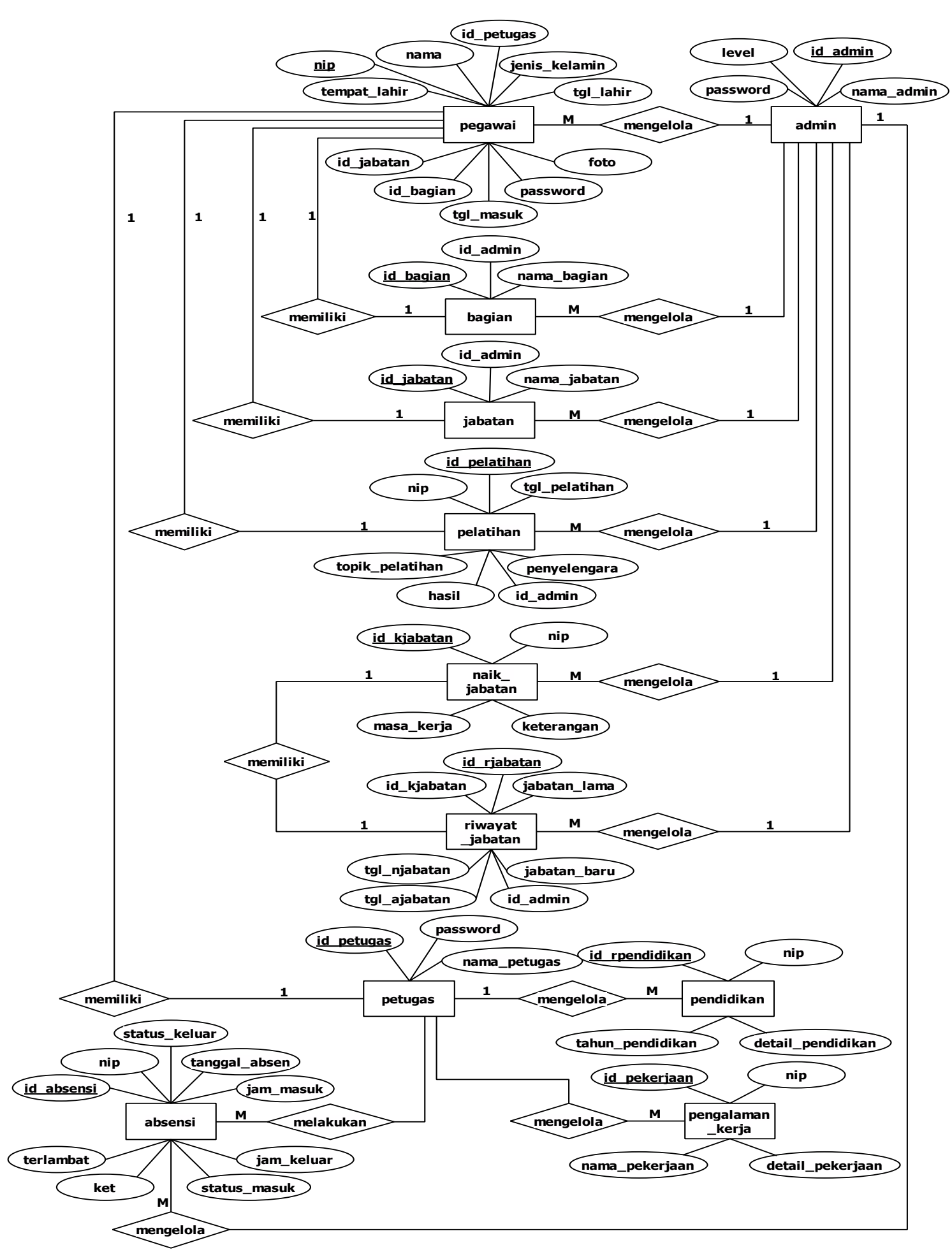

Gambar 2. ERD Sistem

\subsection{Implementasi}

a. Halaman Index Website

Menampilkan pilihan untuk login sebagai administrator website atau login sebagai pegawai dan menampilkan tampilan form pendaftaran pegawai baru. Berikut tampilan halamannya: 


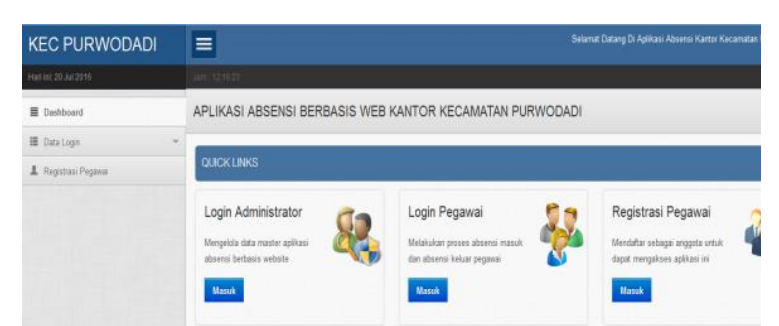

Gambar 3. Halaman Index Website

b. Halaman Login Administrator

Admin harus melakukan login terlebih dahulu sebelum masuk halaman administrator. Berikut tampilan halamannya:

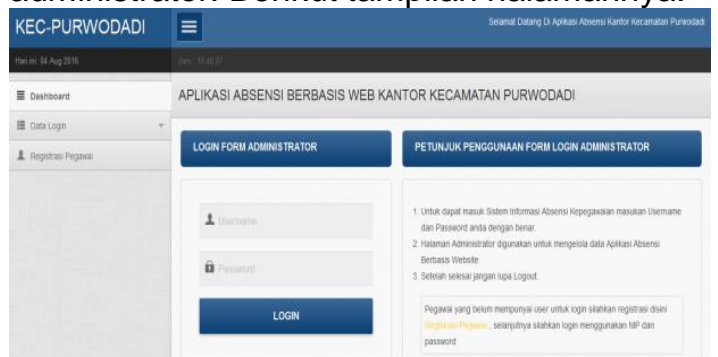

\section{Gambar 4. Login Administrator}

c. Halaman Data Pegawai

Menampilkan data pegawai secara keseluruhan dimana admin dapat melakukan proses melihat, menambah, mengubah, menghapus data pegawai baru. Berikut tampilan halaman data pegawai:

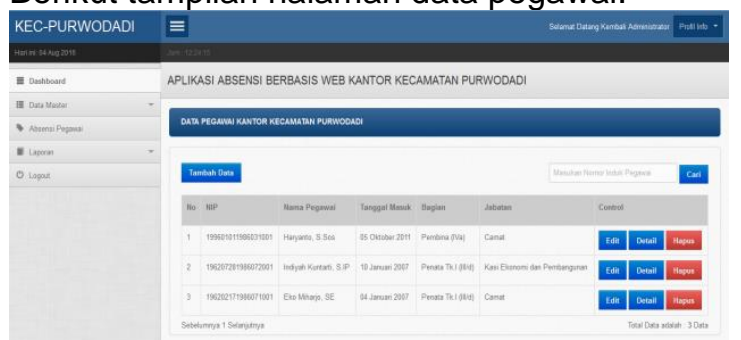

Gambar 5. Halaman Data Pegawai

d. Halaman Data Pelatihan

Halaman baru yang digunakan untuk menampilkan data pelatihan pegawai dimana admin dapat mengelola data di dalamnya yang terdiri atas menambah, mengubah dan menghapus data pelatihan. Berikut tampilan halaman data pelatihan:

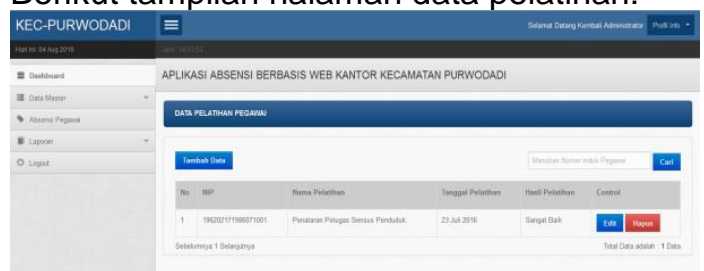

Gambar 6.Halaman Data Naik Jabatan e. Halaman Absensi Pegawai

Halaman baru digunakan untuk menampilkan dan mengelola absensi pegawai. Berikut Halaman absensi

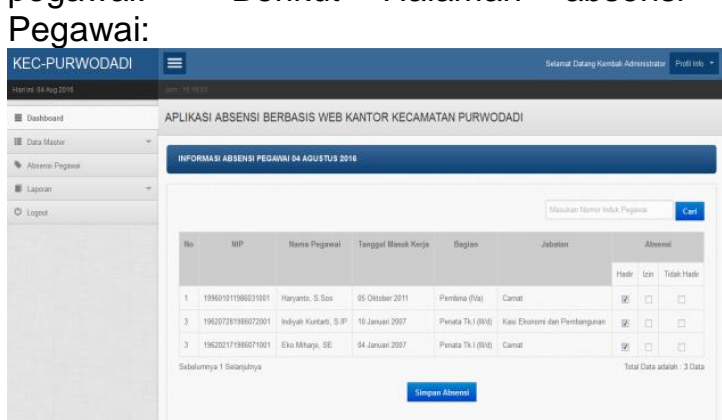

\section{Gambar 7. Absensi Pegawai}

f. Halaman Cetak Data Absensi Pegawai Halaman baru yang digunakan untuk mencetak laporan data absensi pegawai sekaligus bentuk tampilan laporannya. Berikut tampilan halaman cetak data absensi pegawai:

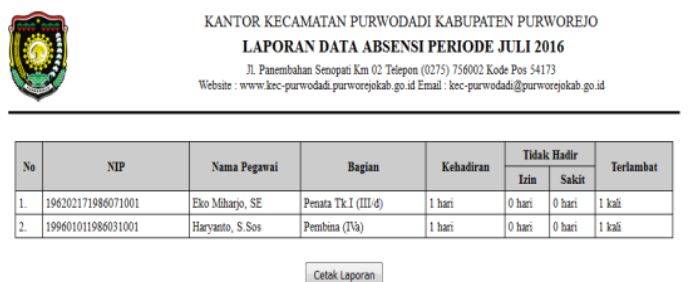

Gambar 8. Cetak Data Absensi Pegawai

g. Halaman Cetak Laporan Data Pelatihan Halaman baru yang digunakan untuk mencetak laporan data pelatihan pegawai sekaligus bentuk tampilannya. Berikut tampilan halaman cetak laporan data pelatihan pegawai:

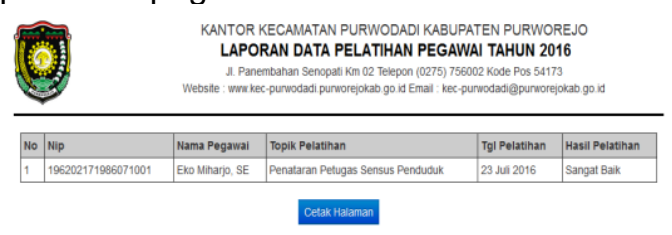

\section{Gambar 9. Cetak Laporan Data Pelatihan}

\subsection{Pengujian}

Hasil pengujian unit yang ditunjukkan pada tabel 1 dapat simpulkan bahwa hasil pengujian sistem menggunakan metode Black Box Testing, semua kebutuhan fungsionalitas yang diinginkan telah memenuhi syarat kriteria atau berjalan dengan lancar. 
Tabel 1. Kesimpulan hasil pengujian unit

\begin{tabular}{|c|c|c|c|c|}
\hline No & $\begin{array}{c}\text { Jenis } \\
\text { pengujian }\end{array}$ & $\begin{array}{c}\text { Validasi } \\
\text { data } \\
\text { Kosong }\end{array}$ & $\begin{array}{c}\text { Valida } \\
\text { si } \\
\text { kesala } \\
\text { han } \\
\text { data }\end{array}$ & $\begin{array}{c}\text { Fungsi- } \\
\text { fungsi } \\
\text { tombol }\end{array}$ \\
\hline 1 & $\begin{array}{c}\text { Login } \\
\text { Admin }\end{array}$ & $\mathrm{V}$ & $\mathrm{V}$ & $\mathrm{V}$ \\
\hline 2 & $\begin{array}{c}\text { Login } \\
\text { Pegawai }\end{array}$ & $\mathrm{V}$ & $\mathrm{V}$ & $\mathrm{V}$ \\
\hline 3 & $\begin{array}{c}\text { Halaman } \\
\text { Admin }\end{array}$ & $\mathrm{V}$ & $\mathrm{V}$ & $\mathrm{V}$ \\
\hline 4 & $\begin{array}{c}\text { Halaman } \\
\text { Pegawai }\end{array}$ & $\mathrm{V}$ & $\mathrm{V}$ & $\mathrm{V}$ \\
\hline
\end{tabular}

\section{Kesimpulan dan Saran}

Berdasarkan pembahasan diatas, maka dapat diambil kesimpulan sebagai berikut :

1. Telah dihasilkan aplikasi absensi berbasis website Kantor Kecamatan Purwodadi yang memberikan kemudahan bagi pegawai dalam mengelola dan mengakses informasi absensi baik dari segi penggunaanya maupun pada proses pembuatan laporan.

2. Dengan menggunakan aplikasi absensi berbasis web pegawai dapat meminimalisir kehilangan dan kesalahan pencatatan data baik dalam proses absensi itu sendiri maupun pembuatan laporan absensi.

3. Data absensi dapat diolah secara terstruktur yang dapat memberikan kemudahan kepada pegawai dalam proses pencarian data absensi.

\section{Saran}

Terdapat saran yang dapat membantu pengembangan aplikasi absensi pada Kantor Kecamatan Purwodadi di masa yang akan datang, antara lain:
1. Bagian Administrator harus melakukan back-up data serta pemeliharaan sistem yang baik dan efektif secara rutin guna mengantisipasi kerusakan pada sistem dan human error.

2. Sistem absensi kepegawaian pada Kantor Kecamatan Purwodadi dapat dikembangkan lagi dengan menggabungkan aplikasi lain seperti finger print.

\section{Referensi}

Binarso, Yusi Ardi, Eko Adi Sarwoko dan Nurdin Bahtiar. 2012. Pembangunan Sistem Informasi Alumni Berbasisi
Web Pada Program Studi Teknik Informatika Universitas Diponegoro. Journal of Informatics and Technology: 72-84. Vol 1 No 1, Tahun 2012. Diambil dari: http://ejournals1.undip.ac.id/index.php/joint/article/v iew/434/434 (27 Juli 2016).

Frieyadie. 2007. Belajar Sendiri Pemograman Database Menggunakan FoxPro 9.0. Jakarta: Elex Media Komputindo.

Hasibuan, Malayu S.P. 2008. Manajemen Sumber Daya Manusia. Jakarta: PT. Bumi Aksara.

Jogiyanto. 2009. Sistem Teknologi Informasi. Yogyakarta : Andi Offset.

Mulyanto, Agus. 2009. Sistem Informasi Konsep dan Aplikasi. Yogyakarta : Pustaka Pelajar.

Peranginangin, Kasiman. 2006. Aplikasi WEB dengan PHP dan MySQL. Yogyakarta: Andi Offset.

Puspitosari, Heni A. 2010. Membangun Website Interaktif dengan Adobe Creative Suite 5. Yogyakarta:PT. Skripta Media Creative.

Rosa, A.S dan M. Shalahuddin. 2013. Rekayasa Perangkat Lunak Terstuktur dan Berorientasi Objek. Bandung: Informatika Bandung.

Setiawan, Parta. 2015. Pengertian Absensi dan Jenis-Jenis Absensi. Diambil dari :http://www.gurupendidikan.com/pen gertian-dan-jenis-jenis-absensi/. (18 Mei 2016).

Utami, Erna dan Anggit Dwi Hartanto. 2012. Sistem Basis Data Menggunakan Microsoft SQL Server 2005. Yogyakarta : Andi Offset. 